Journal of Community Based Environmental Engineering and Management, 2020, Vol. 4, No. 1: 9-14

\title{
FEASIBILITY STUDY ON THE DEVELOPMENT OF INTEGRATED SOLID WASTE TREATMENT FACILITY (TPST) IN SITIREJO MALANG, INDONESIA
}

\author{
Hardianto Hardianto ${ }^{1 *}$, I Nyoman Sudiasa ${ }^{2}$, Mikhael Valerius Seran ${ }^{3}$ \\ 1), 3) Environmental Engineering, National Institute of Technology, Malang, Indonesia \\ ${ }^{2)}$ Civil Engineering, National Institute of Technology, Malang, Indonesia
}

\begin{abstract}
Sitirejo Malang TPST in its implementation can reduce the high generation of solid waste at the source. Reduction of solid waste can be conducted by separating recycleable non organic wastes which in return will gives advantages to local community. Existing solid waste management is only for non composted solid waste. Therefore there is a need for research on the generation, composition and characteristics of solid waste related to the feasibility of developing TPST service areas. The data used in this study include primary data such as generation, composition, and characteristics of solid waste, solid waste processing stages, and solid waste treatment facilities. Secondary data such as TPST service areas, TPST operational and financial technical data. Calculation of solid waste generation using the method of load-count analysis, calculation of the composition of solid waste using the quarterly method, calculation of physical characteristics include the specific gravity of solid waste. In the calculation of financial analysis, the economic criteria used are Net Present Value (NPV), while the feasibility of development uses several development scenarios. The results showed that the treated solid waste were $10.73 \mathrm{~m}^{3} / \mathrm{day}$, while the weight reached $1,071.17 \mathrm{~kg} /$ day. The composition of composted solid waste consists of yard waste of $31.32 \%$ and food waste of $31.18 \%$. The composition of non composted solid waste reaches an average of $0.24 \%-13.18 \%$. The average density of garbage in collecting vehicles is $100.51 \mathrm{~kg} / \mathrm{m}^{3}$. The results of the financial analysis show that the projection until 2028 of $32.5 \mathrm{~m}^{3} /$ day shows a value of NPV>0, thus TPST activities are considered feasible, both the existing and development scenarios.
\end{abstract}

Keywords: development feasibility, solid waste recycling, TPST Sitirejo Malang

\section{Introduction}

Integrated Solid Waste Treatment Facility (TPST) is a place of collecting, sorting, reusing, recycling, processing and final processing of solid waste (Indonesian_Government, 2012). In its implementation TPST can reduce the high generation of garbage in the community and in landfill. Reduction of solid waste can be conducted by separating recycleable non organic

${ }^{*}$ Corresponding Author:

E-mail: hardianto@lecturer.itn.ac.id

Received: 9 January 2020

Revised: 1 February 2020

Accepted: 14 February 2020 wastes which in return will gives advantages to local community (Isyala \& Pharmawati, 2019). Private entities need also involve in the effort of beneficial increment (Banerjee \& Sarkhel, 2020).

The community's view must be changed, where solid waste is seen as raw material, a by-product that can still be processed and is a potential source of income. TPST generally accommodates all types of solid waste produced by the community, ranging from plastic, aluminum, zinc, paper, iron, copper, brass, to glass bottles. 
Sitirejo TPST in Wagir Subdistrict, Malang District has been operated since January 1, 2015. The problem of solid waste has been solved, the community is very enthusiastic about this problem so that with their own awareness the community provides trash bins independently, coordinated by each community chairperson. However, the current handling of solid waste faces many problems because the increase in solid waste generation has not been matched by the provision of adequate facilities and infrastructure. Thereforethe management has not been maximized. In line with the above problems, the aims of this research are:

1. Analyzing the generation, composition, and characteristics of treated solid waste.

2. Analyzing the feasibility scenario of developing solid waste management.

\section{Research Methodology}

This research stage requires some data that will support research including primary data and secondary data. Primary data needed in research include:

1. The piles of treated solid waste is calculated based on the load-count analysis method, by calculating the total volume of solid waste entering the TPST and adjusted to the volume of the collection vehicle. Garbage sampling for 8 days in a row (BSN, 1994).

2. Samples of solid waste composition are taken using the quarterly method (Tchobanoglous, Theisen, \& Vigil, 1993), to obtain a sample of $100 \mathrm{~kg}$. The solid waste component is weighed and a percentage per component is determined from the total weight of incoming solid waste. Types and quantities of products are based on the results of the solid waste components that have been processed and sold to collectors. Data on the type and quantity of this product is used for financial analysis.
3. Density of solid waste can be done by calculating the generation of solid waste expressed from the results of the ratio of weight to volume (Tchobanoglous, Theisen, \& Vigil, 1993).

4. Type and number of solid waste treatment facilities include collection vehicles, container nets, and conveyor belts.

5. Total Human Resources (HR) and TPST organizations that carry out solid waste processing.

6. The amount of residue generated is based on an analysis of material equilibrium.

Secondary data needed in this study include:

1. Data on the quantity of solid waste processed during the past year, to find out the reduction of solid waste by processing solid waste at TPST Sitirejo.

2. Total population and service area, for analysis of technical aspects by reviewing service development projections.

3. Map of Wagir Subdistrict, to adjust the location of existing conditions with the service area in managing solid waste.

4. TPST operational income and expenditure financial data, as well as collectors data, sales prices, and purchasing capacity. This data is useful for financial analysis.

Data analysis was carried out through two aspects, including:

1) Technical Aspects

- Data on the generation and composition of the processed solid waste along with the products and residues produced. This data is useful for calculating mass balance analysis from solid waste processing. Mass balance analysis is used to determine the amount of reduced solid waste. This analysis refers to the results of the analysis of the composition of solid waste $(100 \mathrm{~kg})$ after sorting for each 
component that has a sale/recycling value reduced by residue. For each component of solid waste, a recovery factor (RF) value will be calculated. RF results are determined from the solid waste criteria which have a known selling value by the scavengers/sorting workers. The mass balance diagram illustrates the amount of solid waste that is processed or sold, as well as the amount of solid waste disposed of at the landfill.

- Data on workers, type and number of facilities available, population projections.

2) Financial aspects

- Financial aspects include the type and number of facilities, the amount of productivity, organization and HR of solid waste processing, as well as the types of products produced and sold to collectors. The data needed in the calculation is the income and expenditure data in TPST management. The method of calculating financial analysis uses the net present value method (Giatman, 2006).

- Income data includes the results of sales of solid waste, and the cost of TPST customer fees.

- Expenditure data includes operational and maintenance costs which include electricity costs, employee salaries and incentives, office needs, fuel needs, repair and maintenance of machinery.

\section{Result and Discussion}

\section{Solid Waste Condition}

Solid waste management in Sitirejo Malang TPST faces many problems including a small service area with services $<50 \%$. Inadequate solid waste processing and lack of facilities and infrastructure so that management has not been carried out optimally. At present the processing of solid waste is only limited to the sorting of non composted solid waste to be sold and composted solid waste is disposed of at the Talangagung Landfill Malang, while compost has not been produced due to limited supporting facilities and infrastructure. The results of measurements of solid waste generation can be seen in Table 1.

Table 1. Solid waste generation in TPST

\begin{tabular}{cccc}
\hline Sampling & \multicolumn{3}{c}{ Solid waste generation $\left(\mathbf{m}^{3} / \mathbf{d a y}\right)$} \\
\cline { 2 - 4 } & $\begin{array}{c}\text { Garbage } \\
\text { Cart 1 }\end{array}$ & $\begin{array}{c}\text { Garbage } \\
\text { Cart 2 }\end{array}$ & Total \\
\hline 1 & 675 & 2.94 & 9.69 \\
\hline 2 & 6.75 & 3.15 & 9.9 \\
\hline 3 & 3.5 & 2.94 & 6.44 \\
\hline 4 & 10.75 & 5.67 & 16.42 \\
\hline 5 & 3 & 2.94 & 5.94 \\
\hline 6 & 6.5 & 8.61 & 15.11 \\
\hline 7 & 6.25 & 5.04 & 11.29 \\
\hline 8 & 3.25 & 7.77 & 11.02 \\
\hline Total & 46.75 & 39.06 & 85.87 \\
\hline Average & 5.84 & 4.88 & 10.73 \\
\hline
\end{tabular}

The results of measuring the density of solid waste on the garbage cart can be seen in Table 2 .

Table 2. The average density of solid waste

\begin{tabular}{lc}
\hline Garbage Cart & Average Density $\left(\mathbf{k g} / \mathbf{m}^{\mathbf{3}}\right)$ \\
\hline Garbage Cart 1 & 93.31 \\
\hline Garbage Cart 2 & 107.71 \\
\hline
\end{tabular}

Based on the generation (volume) and average density, the average generation (weight) is as follows:

$$
\begin{aligned}
= & \left(5.84 \mathrm{~m}^{3} / \text { day } \times 93.31 \mathrm{~kg} / \mathrm{m}^{3}\right)+\left(4.8 \mathrm{~m}^{3} /\right. \text { day } \\
& \left.\times 107.71 \mathrm{~kg} / \mathrm{m}^{3}\right) \\
= & 1071.17 \mathrm{~kg} / \text { day }
\end{aligned}
$$

Composition analysis is carried out together with the measurement of solid waste generation. This composition is taken randomly from the number of TPST vehicles taken as much as 100 $\mathrm{kg}$. Based on the criteria given by the sorting workers that the solid waste that is processed at this TPST is very diverse. Based on 23 compositions obtained, 15 types of solid waste that have RF. Garbage that has RF of all types of 
plastic, all types of paper, cans and glass. Food waste, yard waste, diapers, wood, cloth, styrofoam and tissue as residues and transported to landfill. Paper waste has $100 \%$ RF value, this shows that paper waste is completely processed and sold. The results of solid waste and RF composition can be seen in Table 3 .

Table 3. Results of Measurement of Solid waste Composition and Recovery Factor

\begin{tabular}{clcc}
\hline No & $\begin{array}{c}\text { Solid waste } \\
\text { Composition }\end{array}$ & $\begin{array}{c}\text { Percentage } \\
(\%)\end{array}$ & RF \\
\hline 1 & Food Waste & 31.18 & 50 \\
\hline 2 & Yard Waste & 31.32 & 50 \\
\hline 3 & PET & 2.88 & 100 \\
\hline 4 & HDPE & 3.05 & 100 \\
\hline 5 & PVC & 1.05 & 100 \\
\hline 6 & LDPE & 3.60 & 100 \\
\hline 7 & PP & 1.73 & 100 \\
\hline 8 & PS & 0.88 & 100 \\
\hline 9 & Office paper & 0.79 & 100 \\
\hline 10 & Newspapers & 1.43 & 100 \\
\hline 11 & Magazines & 0.59 & 100 \\
\hline 12 & Books & 1.41 & 100 \\
\hline 13 & Paper board & 1.03 & 87.5 \\
\hline 14 & Mixed paper & 2.57 & 100 \\
\hline 15 & Box & 2.05 & 100 \\
\hline 16 & Diapers & 5.18 & 0 \\
\hline 17 & Wood & 1.53 & 0 \\
\hline 18 & Fabric & 3.06 & 0 \\
\hline 19 & Glass & 1.18 & 100 \\
\hline 20 & Cans & 0.53 & 100 \\
\hline 21 & Tissue & 0.62 & 0 \\
\hline 22 & Rubber & 2.10 & 0 \\
\hline 23 & Styrofoam & 0.24 & 0 \\
\hline & & & \\
\hline
\end{tabular}

Composted solid waste is dominated by yard waste by $31.32 \%$, the rest is food waste by $31.18 \%$. Yard waste dominates due to the pattern of community activities in Sitirejo Village. The most common non composted solid waste is plastic waste at $13.18 \%$, paper waste at $9.86 \%$ and diapers at $5.18 \%$. Plastic waste obtained from the results of sampling are types of PET, HDPE, LDPE, PVC, PP and PS. The smallest composition of solid waste is cans by $0.53 \%$ and styrofoam by $0.24 \%$.

After knowing the amount of solid waste that is processed, it can be analyzed through a mass balance diagram that illustrates the amount of solid waste that is processed or sold and the residue that will be transported to the landfill. The results of the analysis showed the presence of residue in TPST was $806.96 \mathrm{~kg}$, which were residual composted solid waste of $669.55 \mathrm{~kg}$ and other untreated non composted solid waste of $136.41 \mathrm{~kg}$. Solid waste sold to TPST partners is $265.21 \mathrm{~kg} /$ day. Total solid waste utilized from the initial weight is $1,071.17 \mathrm{~kg} /$ day $(24.76 \%)$.

\section{Financial Analysis}

Financial aspect analysis is carried out to find out how much profit is obtained by TPST while processing solid waste. This analysis is used to obtain optimum data as a basis for project feasibility (Yansen \& Anantha, 2012). The method used to calculate financial analysis is the NPV method. Income and expenditure costs are as shown in Table 4.

Table 4. Income and Outcome per month

\begin{tabular}{llr}
\hline No & \multicolumn{1}{c}{ Description } & \multicolumn{1}{c}{ Amount (IDR) } \\
\hline \multicolumn{2}{c}{ Income } \\
\hline 1 & RT / RW contributions & 852,000 \\
\hline 2 & Sales & $4,000,000$ \\
\hline 3 & Other contributions & $1,500,000$ \\
\hline \multicolumn{2}{c}{ Total Income } & $6,352,000$ \\
\hline \multicolumn{2}{c}{ Expenditure } \\
\hline 2 & Fuel Needs & $5,100,000$ \\
\hline 3 & Maintenance & 250,000 \\
\hline 4 & Electrical Needs & 200,000 \\
\hline 5 & Water & 50,000 \\
\hline 6 & Office stationery & 50,000 \\
\hline & Total Expenditure & 100,000 \\
\hline
\end{tabular}

The initial step in conducting this analysis is to calculate the cash flow of a project from the 
income and expenditure data for the past year. The total income and expenditure per year will be used as the basis for determining the project's cash flow. Cash flow is determined by the difference between income and expenses from the first year to the second year when TPST operates.

The calculation of net cash flow received is IDR $8,824,000$,- and can be said to experience a profit even though the amount is not too large. Smaller TPST will give lower profit (Dwi Siwi Handayani, 2009). In the year of 2017, the cash flow will be assumed as the amount of TPST investment. NPV value on the calculation results that the number $>0$. Next is to calculate the NPV in 2018 until 2028.

Table 5. Determination of TPST Feasibility

\begin{tabular}{ccc}
\hline & $\begin{array}{c}\text { Existing } \\
\text { Scenarios }\end{array}$ & $\begin{array}{c}\text { Scenarios } \\
\text { according to } \\
\text { District Minimum } \\
\text { Wages }\end{array}$ \\
\hline $\begin{array}{c}\text { Total NPV } \\
\text { (IDR) }\end{array}$ & $681,803,037$ & $369,278,383$ \\
\hline $\begin{array}{c}\text { Initial } \\
\text { capital } \\
\text { (IDR) }\end{array}$ & $7,824,000$ & $7,824,000$ \\
\hline Status & Profitable & Profitable \\
\hline $\begin{array}{c}\text { Feasibility } \\
\text { Status }\end{array}$ & Feasible & Feasible \\
\hline
\end{tabular}

The results of the analysis according to Table 5 show that based on the existing scenario and according to the scenario according to the district minimum wage the results are still feasible to be developed.

\section{Conclusion}

The results obtained from this study include:

1. The generation of solid waste that is processed every day at Sitirejo TPST is $10.73 \mathrm{~m}^{3} /$ day with a solid waste weight of $1,071.17 \mathrm{~kg} /$ day. The composition of solid waste includes yard waste by $31.32 \%$, food waste by $31.18 \%$, and non composted solid waste on average reaches $0.24 \%-13.18 \%$. The density in garbage collectors is on average $100.51 \mathrm{~kg} / \mathrm{m}^{3}$.

2. The results of financial analysis show that the volume of solid waste is $10.73 \mathrm{~m}^{3} /$ day in 2018 and the 10-year projection of 32.5 $\mathrm{m}^{3} /$ day in 2028 shows the value of NPV> 0 . Therefore, TPST activities are considered appropriate for all scenarios.

\section{References}

Banerjee, S., \& Sarkhel, P. (2020). Municipal solid waste management, household and local government participation: a cross country analysis. Journal of Environmental Planning and Management, Vol. 63, issue 2, pp. 210235.

BSN, B. N. (1994). SNI 19-394-1994 tentang Metode Pengambilan dan Pengukuran Contoh Timbulan dan Komposisi Sampah Perkotaan.

Dwi Siwi Handayani, S. H. (2009). Kajian Nilai Ekonomi Penerapan Konsep Daur Ulang pada TPA Jatibarang Kota Semarang. Jurnal Presipitasi, Vol. 7, No. 2, pp. 3544.

Giatman, M. (2006). Ekonomi Teknik. Jakarta: Raja Grafindo Persada.

Indonesian_Government. (2012). Peraturan Pemerintah RI Nomor 18 Tahun 2012 tentang Pengelolaan Sampah Rumah Tangga dan Sampah Sejenis Sampah Rumah Tangga.

Isyala, R. K., \& Pharmawati, K. (2019). Pengembangan Pengelolaan Sistem Persampahan Area Wisata Grama Tirta Jatiluhur Menggunakan Prinsip Contingent Valuation Method. Journal of Community Based Environmental Engineering and Management, Vol. 3, No. 2, pp. 57-64. 
Tchobanoglous, G., Theisen, H., \& Vigil, S. (1993). Integrated solid solid waste management: engineering principles and management issues. . McGraw-Hill, Inc.
Yansen, I., \& Anantha, I. M. (2012). Analisis Finansial Pengelolaan Sampah di Wilayah Kecamatan Mengwi Kabupaten Badung. Jurnal Ilmiah Teknik Sipil . 